University of Nebraska - Lincoln

DigitalCommons@University of Nebraska - Lincoln

USDA National Wildlife Research Center - Staff Publications
U.S. Department of Agriculture: Animal and Plant Health Inspection Service

December 2003

\title{
Nonlethal Techniques for Managing Predation: Primary and Secondary Repellents
}

\author{
John A. Shivik \\ Wildlife Services, National Wildlife Research Center and Utah State University, Room 163 BNR Building, \\ Utath State University, Logan UT \\ Adrian Treves \\ Center for Applied Biodiversity Science, Conservation International \\ Peggy Callahan \\ USDA-APHIS-Wildlife Services
}

Follow this and additional works at: https://digitalcommons.unl.edu/icwdm_usdanwrc

Part of the Environmental Sciences Commons

Shivik, John A.; Treves, Adrian; and Callahan, Peggy, "Nonlethal Techniques for Managing Predation: Primary and Secondary Repellents" (2003). USDA National Wildlife Research Center - Staff Publications. 272.

https://digitalcommons.unl.edu/icwdm_usdanwrc/272

This Article is brought to you for free and open access by the U.S. Department of Agriculture: Animal and Plant Health Inspection Service at DigitalCommons@University of Nebraska - Lincoln. It has been accepted for inclusion in USDA National Wildlife Research Center - Staff Publications by an authorized administrator of DigitalCommons@University of Nebraska - Lincoln. 


\title{
Nonlethal Techniques for Managing Predation: Primary and Secondary Repellents
}

\author{
JOHN A. SHIVIK, ${ }^{*}$ ADRIAN TREVES, $†$ AND PEGGY CALLAHAN $\ddagger$ \\ ${ }^{*}$ Wildlife Services, National Wildlife Research Center and Utah State University, Room 163 BNR Building, \\ Utah State University, Logan, UT 84322 U.S.A., email john.shivik@aphis.usda.gov \\ fCenter for Applied Biodiversity Science, Conservation International, 6010 South Hill Drive Madison, WI 53705, U.S.A. \\ ‡Wildlife Science Center, 5463 West Broadway, Forest Lake, MN 55025, U.S.A.
}

\begin{abstract}
Conservation biology requires the development of practical tools and techniques to minimize conflicts arising from buman modification of ecosystems. We applied behavioral theory of primary and secondary repellents to predator management by using aversive stimulus devices (electronic training collars) and disruptive stimulus devices (bebavior-contingent audio and visual repellents) in a multipredator (Canis lupus, Haliaeetus leucocephalus, Ursus spp.) study in the United States. We examined fladry and a newly developed disruptive stimulus device contingent upon bebavior on six wolf territories in Wisconsin, (U.S.A.) and determined that the disruptive stimulus device gave the greatest degree of protection from predation. We also compared the efficacy of a primary repellent (disruptive stimulus device) versus a secondary repellent (electronic training collars) to keep captive wolves from consuming a food source. Disruptive stimulus devices effectively prevented captive wolves from consuming the food resource, but did not produce an aversion to that food resource. With training collars, logistical and bebavioral variability limited our ability to condition wolves. Our studies bighlight the complexity of application of nonlethal techniques in real-world situations.
\end{abstract}

Técnicas no Letales para Gestión de la Depredación: Repelentes Primarios y Secundarios

Resumen: La biología de la conservación requiere del desarrollo de herramientas y técnicas prácticas para minimizar los conflictos derivados de la modificación de ecosistemas por bumanos. Aplicamos la teoría conductual de repelentes primarios y secundarios a la gestión de depredadores por medio de dispositivos de estímulos de aversión (collares electrónicos de entrenamiento) y dispositivos de estímulos disruptivos (repelentes conducta-contingentes visuales y auditivos) en un estudio de depredadores múltiples (Canis lupus, Haliaeetus leucocephalus, Ursus spp.) en los Estados Unidos. Examinamos fladry y un dispositivo de estímulos disruptivos recientemente desarrollado en seis territorios de lobos en Wisconsin (E.U.A.) y determinamos que el dispositivo de estímulos disruptivos proporcionó el mayor grado de protección a la depredación. También comparamos la eficacia de un repelente primario (dispositivo de estímulo disruptivo) versus un repelente secundario (collares electrónicos de entrenamiento) para impedir que lobos cautivos consumieran una fuente de alimento. Los dispositivos de estímulos disruptivos previnieron eficientemente que los lobos cautivos consumieran el recurso alimenticio, pero no produjeron aversión a esa fuente de alimento. Con los collares de entrenamiento, la variabilidad logística y conductual limitó nuestra capacidad para condicionar a los lobos. Nuestros estudios resaltan la complejidad de la aplicación de técnicas no letales en situaciones reales.

\section{Introduction}

Conservation biology is as much about the interface between theory and practice as it is the science of scarcity and diversity (Soulé 1986). To promote the existence and expansion of large carnivores, conservation biologists should assist with the real-world problems predators cause. Therefore, we continue to investigate and develop applied techniques for predation management to identify a variety of alternative methods for solving the growing

Paper submitted February 3, 2003; revised manuscript accepted May 18, 2003. 
number of conflicts between humans and wildlife. New, especially nonlethal, tools for management are important for us as conservation biologists in our interface with the public and policy-makers, and the concepts we describe here are designed to help us to effectively operate within this real world.

Where predators live, the people directly affected by large predators (and most likely to directly affect the predators, lethally, illegally, or otherwise) are influenced by their own educational and value systems (Primm \& Clark 1996), which often conflict with those of many conservation biologists. It is important to acknowledge the attitudes of the humans living sympatrically with predators and to provide small-scale solutions to conflicts. Our assistance with predation problems may counteract a perception that conservation values only result in adversity for those directly affected by predator-conservation policies.

Lethal control of predators can effectively end predation on cattle, dogs, sheep, and other domestic animals. However, the goal of rare-carnivore management is to reclaim viable populations of predators, and lethal management actions slow the process of building populations. Furthermore, there is a strong correlation (probably causative) between predator-livestock conflicts and the subsequent removal of predators (Fig. 1). Rare-carnivore management involves encouraging the survival and reproduction of individual predators, which, especially in the early stages of recovery, means

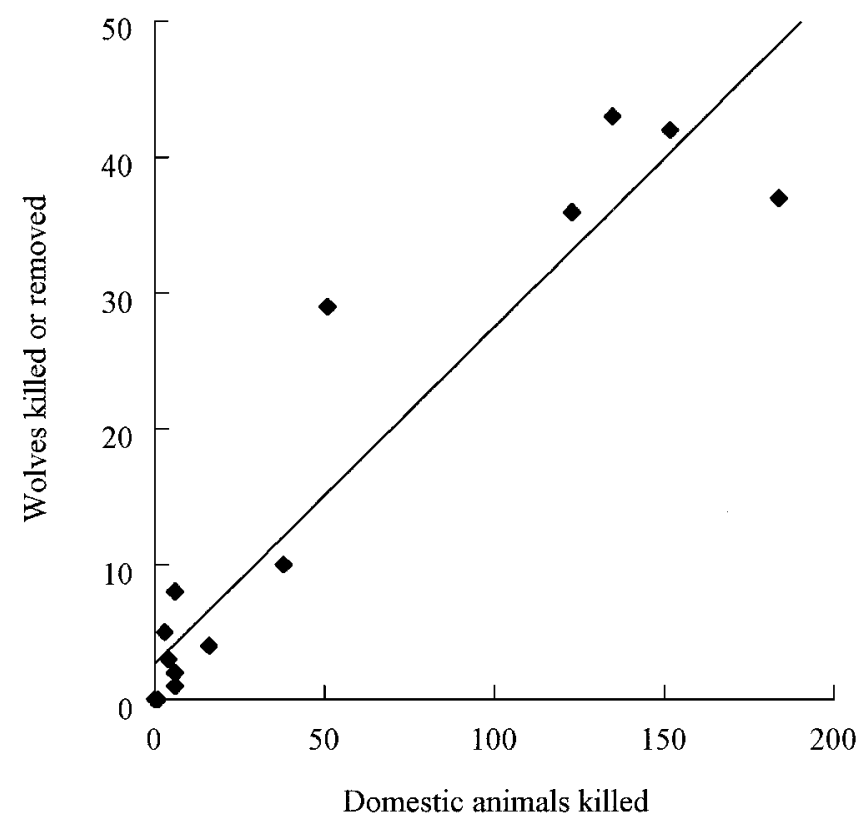

Figure 1. Correlation between numbers of livestock killed and numbers of wolves killed or removed in the Rocky Mountain region of the United States. Data are from U.S. Fish and Wildife Service (USFWS 2002) $\left(\mathrm{y}=0.25 \mathrm{x}+2.68 ; \mathrm{p}<0.001, \mathrm{R}^{2}=0.89\right)$. keeping individual predators from coming into conflict with humans. Also, with highly social predators such as wolves (Canis lupus) the important biological unit, in terms of social transfer of knowledge, is the pack and not necessarily the absolute number of wolves. Even a population of hundreds or thousands may not be a healthy ecological and behavioral unit under highly exploited lethal management schemes (Haber 1996). Thus, it is preferable from a biological point of view to maintain natural predator demographics and behavior while attempting to minimize the conflicts between humans and wildlife. Although territoriality in canids may not wholly preclude interlopers, territoriality does limit interpack access to a domestic animal resource (Shivik et al. 1996). Thus, nonlethal techniques that preserve stabilization of social and demographic structure may limit conflicts with humans and have additional benefits in management efficiency. That is, removal of territorial predators results in a breakdown of territorial defense and allows access to livestock by predators that were formerly excluded. Nonlethal methods for managing predation allow continuance of territorial defense and may have longer-term effects by preventing other predators from intruding into an area containing livestock. Furthermore, efficiency of nonlethal techniques may be greater because they can last beyond the year of management (Bromley \& Gese 2001).

We present two conceptual approaches to nonlethal tool development, testing, and application and describe concepts and examine case studies of how tools and techniques for predation management were identified and tested. With additional knowledge and understanding of nonlethal techniques that are available or in development, the conservation community may more effectively employ these nonlethal tools when most appropriate.

\section{Primary Repellents}

Primary repellents are those that immediately disrupt a predator's actions through a number of mechanisms such as neophobia, irritation, or pain (Clark 1997; Mason et al. 2001). Stimuli that are applied as primary repellents are disruptive stimuli because they disrupt normal behaviors of an animal (e.g., a light and siren combination that may disrupt the normal progression of a predator's stalk or attack). These stimuli may be chemical, visual, or auditory in nature.

Fladry is an example of a disruptive stimulus that has been used recently for wolf predation management (Musiani \& Visalberghi 2001; Musiani et al. 2003 [this issue]). Fladry is an ancient Eastern European technique used to control wolf movements during capture that has been successfully modified for use as an exclusionary device for captive wolves, and it may be possible to prevent 
intrusion by wild wolves with flagging hung on fence lines (Musiani et al. 2003 [this issue]).

Flashing highway lights and sirens have been used as disruptive stimuli to deter wolves on farms in Minnesota (Fritts 1982; Fritts et al. 1992), although the degree of effectiveness is unknown. Other researchers reported that electronic guards (a siren and strobe device that activates randomly at night) are effective for preventing predation by coyotes (Linhart et al. 1984). Little other research has been conducted to test the effect of frightening devices on reducing livestock depredations by wolves (Smith et al. 2000), probably because investigations usually concluded that light and sound stimuli are limited in usefulness because of habituation (Bombford \& O'Brien 1990; Koehler et al. 1990). Primary repellents are limited in their effectiveness because of habituation, and unless disruptive stimuli are sufficiently noxious to prevent an animal from continuing a behavior, the continued use of the disruptive stimuli will result in an extinction of the neophobic effect. The effectiveness of disruptive stimuli can be prolonged by randomizing stimuli and location and by using behavior-contingent technologies that selectively activate dependent upon behavior of the predator being repelled (Shivik \& Martin 2001).

One disruptive stimulus approach to livestock protection resulted in the development of an animal-activated disruptive stimulus device for wolves (more commonly referred to as a radio activated guard [RAG], Shivik \& Martin 2001). The current version of the RAG system is commercially available as the Model 9000 Frightening Device (Avian Systems Louisville, Kentucky) and is designed to keep radiocollared predators out of small ( $<16 \mathrm{ha}$ ) areas, such as those containing infant livestock. Activation of the device triggers a strobe light and loud sound effects. To reduce the ability of animals to habituate to the device, there are 30 different recorded sounds. The devices are currently being employed in Idaho, with indications of substantial, but not unlimited effectiveness (Breck et al. 2002).

\section{Secondary Repellents}

Whereas primary repellents rely on novelty and are rendered ineffective due to animal learning, secondary repellents rely on animal learning to become effective. That is, secondary repellents are linked to a behavior and result in aversive conditioning after a link is established between a behavior and a negative outcome. Aversive stimuli cause discomfort, pain, or an otherwise negative experience and are paired with specific behaviors to reduce the occurrence of these behaviors (Shivik \& Martin 2001). Aversive stimuli are often difficult to apply in management situations, usually because controlling the specificity of aversion to an area or prey item can be difficult (e.g., a bear that receives a negative stimulus from a rubber bullet will not necessarily form an aversion to the area where it was shot, but will often learn to avoid the person who shot it instead). However, because fields of theory and evolution are based on aversive conditioning in natural conditions (e.g., aposomatic indicators), it is safe to assume these concepts can be employed in such a way that they are useful for protecting a resource of immediate human concern. For example, Gustavson et al. (1974) suggest that aversive conditioning, through the mechanism of conditioned taste aversion, may be an effective management tool, although conditioned taste aversion is more useful for reducing consumptive behaviors of particular foods rather than for limiting killing behavior by predators (Conover \& Kessler 1994). Similarly, the concept and theory of using electric shock as aversive stimuli to alter domestic animal and wildlife behavior has been intensively studied (Krane \& Wagner 1975; Linhart et al. 1976; Quigley et al. 1990; Tiedeman et al. 1997). Andelt et al. (1999) recently demonstrated the effectiveness of domestic-dog training collars for conditioning coyotes, and Shivik et al. (2002) expanded this concept, applying it to wild wolves.

\section{Methods}

\section{Case Study 1: Primary Repellents in Wolf Territories in Wisconsin (U.S.A.)}

Attack and kill behaviors are separate and distinct from consumption behaviors for predation management (Klunder \& O'Boyle 1979; Sterner 1995). However, because experimental evaluations of depredation control technologies are difficult to implement in actual management situations, we tested two repellents for their efficacy in reducing consumption only. We tested the effectiveness of two disruptive stimulus approaches (fladry and a behavior-contingent light and sound device) and used deer carcasses as an attractive resource placed in wolf territories in northwest Wisconsin.

Six wolf packs (Bird Sanctuary, Casey Creek, Chain Lake, Crotte Creek, Shoberg, and Tranus Lake) were identified from long-term monitoring by the Wisconsin Department of Natural Resources (Wydeven et al. 1995 , 2002). Within each pack, we installed three plots. To construct plots, we located a wooded site within an area that was known to contain wolves but was $>500 \mathrm{~m}$ from an historic den site and $>100 \mathrm{~m}$ from a road. We demarcated the boundary of a plot with nylon rope and constructed a virtual fence by stringing cord at approximately 1.3 and $0.3 \mathrm{~m}$ on existing vegetation. Each plot was approximately $30 \mathrm{~m}$ in circumference and teardrop shaped. A road-killed deer carcass was placed within the center of the plot. All carcasses were obtained in good condition (intact and relatively fresh) and were stored frozen until needed. A technician visited the plots at 2- to 3-day intervals, inspected the area for predator sign, and examined 
the condition of the carcass, including measuring the carcass weight. Plots in the Bird Sanctuary, Chain Lake, and Shoberg packs were monitored with movement-activated night-vision cameras to positively identify species visitation to plots. A carcass was removed and replaced with a "fresh" carcass when one of the following criteria were met: (1) all muscle mass and viscera were gone, (2) most of the muscle and viscera were gone and the reduction of weight through time reached an asymptote, (3) another plot in the pack recently had a carcass replaced (within 6 days), or (4) a carcass had been sitting on a plot for 2 weeks.

Plots were installed sequentially within each pack territory and maintained for 9-35 days pretreatment (beginning 4 April 2002) and then 16-29 days during treatment (ending 7 June 2002). Treatments were (1) a movementactivated guard device (MAG), which used light (strobe light) and sound (30 recorded sound effects including yelling, gunfire, and helicopters) stimuli used by Breck et al. (2002) but was activated (with a passive infrared detector) by movement of a large animal proximal to the carcass, (2) strips of $1 \mathrm{~m} \times 7.5 \mathrm{~cm}$ red flagging suspended between ropes serving as fladry, and (3) a control site with no protection from predation. We measured the proportion of carcasses consumed per day on each plot. To avoid pseudoreplication, we used the pack as the sample unit for analysis. That is, in statistical tests differences in mean daily consumption were based on a sample size of six per treatment. We tested for differences in mean daily consumption on plots before and during treatment with analysis of variance (ANOVA), with post-hoc multiple comparisons made using the Tukey method.

\section{Case Study 2: Primary and Secondary Repellents on Penned Wolves in Minnesota (U.S.A.)}

We evaluated aversive and disruptive stimulus approaches for managing predation with captive wolves at the Wildlife Science Center, Forest Lake, Minnesota. The first treatment was a MAG device. The device was installed such that an approach within $2 \mathrm{~m}$ of a unique food source (sled-dog chow) would activate the light and sound stimuli of the behavior-contingent disruptive stimulus device. The second treatment was an electronic training collar set to activate if a wolf approached within $2 \mathrm{~m}$ of the food source (by burying collar-activation wires beneath the area where the food source was placed). The final treatment was a control with the food source unprotected.

Social groups were not mixed during this study, and wolves remained in their home pens at the Wildlife Science Center (although one group was separated into two by closing a barrier that transected the middle of their pen). We stratified by group size and then randomly assigned treatments to 14 groups of mixed size, sex, and age class. We performed initial trials during June and July
2002. Wolves assigned the collar treatment were in four groups of one, two, three, and four animals. Wolves assigned the MAG treatment were in six groups of one, two, three, four, six, and seven animals each. Four control groups had one, two, three, and four wolves. Trials were run for 1 hour and began when the food source was placed in the pen with the wolves. We measured the proportion of the $1-\mathrm{kg}$ portion that was consumed by wolves during the duration of the trial. Training collars were affixed 1-2 days before the first trial, left on wolves, and checked periodically. We retested (post-treatment) wolves in August 2002 after collars and MAG devices were removed. Some penned wolves were removed or relocated (from causes independent of treatments), and we were unable to retest each original group in posttreatment trials. Therefore, the wolves that remained for post-treatment trials were from five groups of the MAG treatment (one, three, four, six, seven animals per group, respectively), one group of two wolves in the training collar treatment and two groups of wolves (one and two animals per group) in the control treatment.

So we could extrapolate our results to wolf packs in the wild, we measured the effectiveness of the MAG and collar treatments for limiting consumption behavior and used the group as the sample unit. That is, the dependent variable was the proportion of food consumed per group. We used ANOVA to detect differences in mean consumption per group and made post hoc multiple comparisons with the Tukey method.

\section{Results}

\section{Case Study 1: Primary Repellents in Wolf Territories in Wisconsin}

Our preliminary analysis suggested the effectiveness of the MAG device for protecting the carcass resource from predators. The average weight of consumption per day was similar on all plots before treatments were applied $(p=0.771$, Fig. 2). Consumption increased on control and fladry plots but was reduced on MAG plots during the treatment period. When treatments were applied, carcass consumption was different depending on treatment (ANOVA, $p=0.032$ ), and the average daily consumption on MAG-protected plots was $68 \%$ less than that on control plots ( $p=0.028$, Fig. 2 ). Consumption on the fladry plots was not statistically less than on the control plots $(p=0.583)$ or more than MAG plots $(p=0.174)$. We positively identified black bears (Ursus americanus), Crows (Corvus brachyrbynchos), Bald Eagles (Haliaeetus leucocephalus), fishers (Martes pennanti), foxes (Vulpes vulpes), Turkey Vultures (Cathartes aura), and wolves visiting the carcass sites. Most carcass consumption resulted from black bear and Bald Eagle activity, although we were not able to precisely quantify consumption by species. 


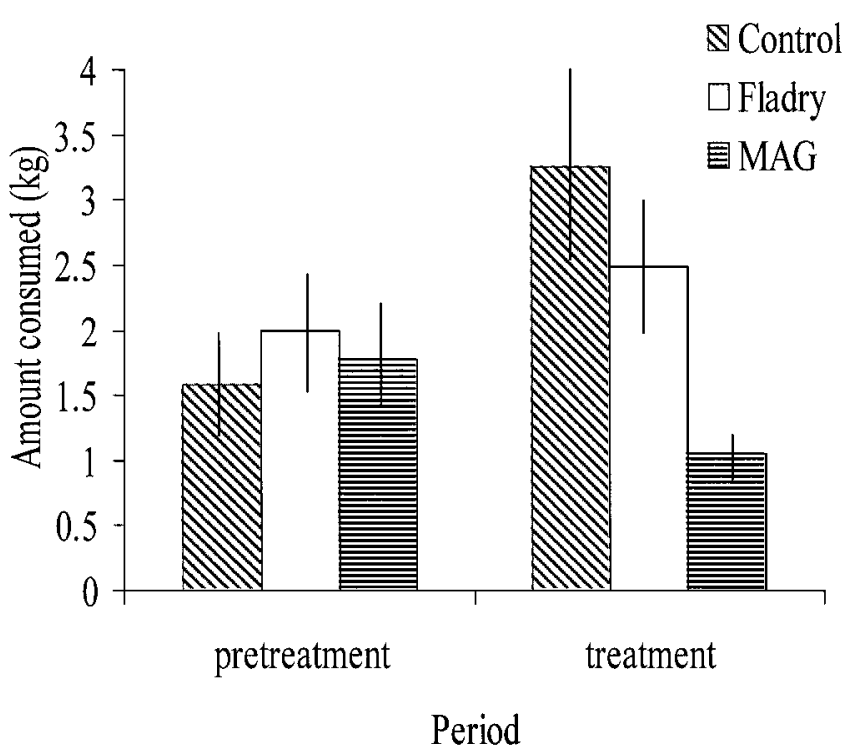

Figure 2. Mean ( \pm 1 SE) predator consumption of carcass resource per day during periods before treatments were in place (pretreatment) and after they were in place (treatment) in northwest Wisconsin, spring 2002 ( $\mathrm{n}=6$ per treatment group) (MAG, movement activated guard).

\section{Case Study 2: Primary and Secondary Repellents on Penned Wolves in Minnesota}

The measurement of food consumed by wolves indicated a significant treatment effect $(p=0.014)$. That is, less food was consumed using the disruptive stimulus device than in the control treatment ( $p=0.011$; Fig. 3), but effectiveness of the training collar was not evident $(p=$ 0.33 ). During all post-treatment trials, all food was completely consumed by wolves in the collar, MAG, and control groups.

\section{Discussion}

In multipredator ecosystems, protective methods that prevent predation on human resources by various predators are desired. Fladry has limited effectiveness for wolves (Musiani et al., 2003 [this issue]), but it does not appear to be as effective for other predatory species. The MAG technology, however, repelled all vertebrate consumers until the conclusion of the study. We hypothesize that the behavior-contingent disruptive stimulus concept will be useful in apiary and other small-area applications to protect resources from bears and may also be applied to protect some species (e.g., endangered ferrets [Mustela nigripes]) from avian predators. In some instances the devices may be quicker and easier to install. Other benefits are possible: the frightening stimuli may warn species such as ferrets (or humans protecting livestock)

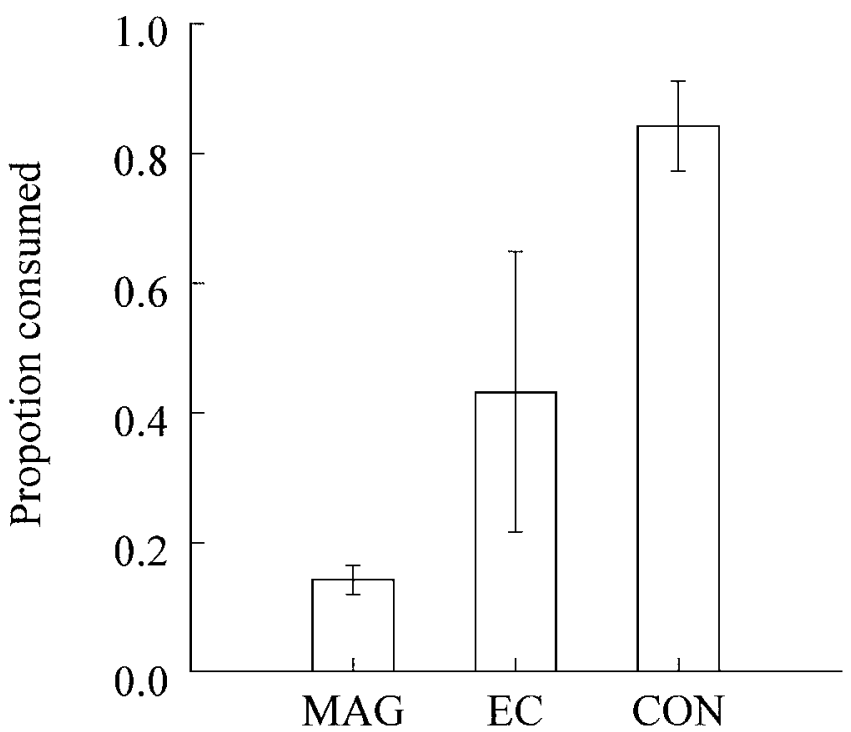

Figure 3. Mean ( 11 SE) proportion of food source consumed by captive wolves in Forest Lake, Minnesota, summer $2002(\mathrm{n}=6,4$, and 4 for movement activated guard [MAG], electronic training collar [EC], and control [CON], respectively).

of approaching predators and further increase survival probabilities.

We did not evaluate the duration of effectiveness for the MAG device, but such research is necessary, especially because differential response is likely from various predators. For example, a stereotypical aspect of canid predators is that they seem to be inherently "wary" (Harris \& Knowlton 2001) and are thus more likely to be susceptible (i.e., less quick to habituate than, e.g., usrine predators) to simple disruptive stimuli. Lastly, effectiveness of disruptive stimuli is possibly influenced by availability of alternative food resources and if unprotected food resources are not available, the effectiveness of any nonlethal technique will be limited. We designed our study to give predators within each wolf territory a choice between treatments, and we measured relative consumption based on protective method. The availability of alternative, unprotected food resources probably influences the consumption rate on protected resources, and future studies should measure the effectiveness of repellents when no alternative food supply is provided.

In this and other studies, researchers reported that electronic training collars were difficult to use with wolves (Shivik et al. 2002). Although fur was trimmed and all collars were fitted to the same snugness, we observed a wide variability in response (Fig. 3). Some wolves found the stimuli very noxious and immediately jumped, yelped, and ran away from the food source. Others, however, acted as if the stimulus from the collar was mildly annoying, if at all, and continued to consume the food resource. 
One female wolf sat and scratched at the device but did not retreat from the area upon activation of the collar. After four trials, we were unable to show conditioning against the food resource and submit that substantial logistical, animal care, and maintenance issues, and variation in wolf response to the electronic collar complicates application of this type of aversive conditioning into management programs. Furthermore, difficulty in producing aversions to consumptive behavior has been observed (Garcia \& Koelling 1966), although other researchers showed that reduction of consumptive behaviors using electrical stimuli is possible (Krane \& Wagner 1975; Klunder \& O'Boyle 1979). Linhart et al. (1976) and Andelt et al. (1999) demonstrated the effectiveness of electronic training collars for minimizing attack behavior from coyotes.

In our studies, primary repellents were easier to apply and thus more "management friendly" than secondary repellents. However, we believe that limitations of application of secondary repellents are not due to theoretical limitations of the technique, but to logistical difficulties and differential response to the aversive stimulus used. Technological advancement is possible that would prevent tissue irritation (such as implantable conditioning units), but readily available technology must be considered carefully before broad-scale application in predation management. Based on previous reports on penned animals, we believe it is possible to condition predators to not attack livestock (Linhart et al. 1976; Andelt et al. 1999) but acknowledge the need to overcome the difficulties of using training collars on wild predators (Shivik et al. 2002).

In our pen experiments, the primary repellent functioned as expected and no conditioning occurred. Furthermore, in our field experiment, no generalization or conditioning from the disruptive stimuli was evident because predators apparently only limited consumption on protected plots and did not generalize and avoid control plots. This experiment emphasizes the specificity of application of nonlethal techniques; there is no one inexpensive, simple, nonlethal technique that will provide protection across an ecosystem. Real-world applications for predation management in conservation biology should minimize logistical difficulties. Thus, based on our preliminary studies in nonlethal techniques for predation management, current methodology favors the use of primary repellent approaches in managing predation, albeit there are substantial limitations associated with using primary repellents. Failure of nonlethal techniques may result from misapplication or logistical difficulties rather than a basic unsuitability of the behavioral concepts of nonlethal predation management. Animal behavior is a complicated field in itself, but basic tenets must be understood to prevent wasteful misapplication of nonlethal methods (Caro \& Durant 1995; Clemmons \& Buchholz 1997).
Clark et al. (1996) note that problem definition is an important aspect of improving conservation efforts. Clearly, when cultural history, ecology, management, and the policy process conflict, reasonable compromises must be identified to mollify all parties. Nonlethal approaches to managing predation are not without costs and limitations, but they do provide a means for conservation biologists to target areas with high predation levels and increase acceptance of large mammalian predators. Furthermore, we acknowledge that nonlethal approaches to predator management may be frustrating to managers with limited resources. High-technology devices are much more expensive, complicated, and limited in effectiveness than a single bullet from a high-powered rifle, but they also allow a predator to live-surely the goal of conservation.

\section{Acknowledgments}

We thank K. Martin and N. Lance for their diligence and skills performing fieldwork, A. Wydeven and all associated personnel at the Wisconsin Department of Natural Resources, B. Hawkinson for providing deer carcasses, and supporters and personnel of the Wildlife Science Center. This work was completed under auspices of the National Wildlife Research Center's Project (NWRC), Alternative Capture Systems and Aversive Stimulus Applications for Managing Predation, with financial support for the Wyoming Animal Damage Management Board and financial and other aid from the Born Free Foundation. All protocols were approved by the NWRC and the Wildlife Science Center Institutional Animal Care and Use Committees.

\section{Literature Cited}

Andelt, W. F., R. L. Phillips, K. S. Gruver, and J. W. Guthrie. 1999. Coyote predation on domestic sheep deterred with electronic dog-training collar. Wildlife Society Bulletin 27:12-18.

Bombford, M., and P. H. O'Brien. 1990. Sonic deterrents in animal damage control: a review of device tests and effectiveness. Wildlife Society Bulletin 18:411-422.

Breck, S. W., R. Williamson, C. Niemeyer, and J. A. Shivik. 2002. Nonlethal radio activated guard for deterring wolf depredation in Idaho: summary and call for research. Proceedings of the Vertebrate Pest Conference 20:223-226.

Bromley, C., and E. M. Gese. 2001. Surgical sterilization as a method of reducing coyote predation on domestic sheep. Journal of Wildlife Management 65:510-519.

Clark, L. 1997. Physiological, ecological, and evolutionary bases for the avoidance of chemical irritants by birds. Pages 1-37 in V. Nolan Jr. et al., editors. Current ornithology. Volume 14. Plenum Press, New York.

Clark, T.M., A.P. Curlee, and R.P. Reading. 1996. Crafting effective solutions to the large carnivore conservation problem. Conservation Biology 10:940-948.

Caro, T. M., and S. M. Durant. 1995. The importance of behavioral ecology for conservation biology: examples from Serengeti carnivores. Pages 451-472 in A. R. E. Sinclair and P. Arcese, editors. Serengeti II. University of Chicago, Chicago. 
Clemmons, J. R., and R. Buchholz, editors. 1997. Behavioral approaches to conservation in the wild. Cambridge University Press, Cambridge, United Kingdom.

Conover, M. R., and K. K. Kessler. 1994. Diminished producer participation in an aversive conditioning program to reduce coyote depredation on sheep. Wildlife Society Bulletin 22:229233.

Fritts, S. H. 1982. Wolf depredation on livestock in Minnesota. Research publication 145. U.S. Fish and Wildlife Service, Washington, D.C.

Fritts, S. H., W. J. Paul, L. D. Mech, and D. P. Scott. 1992. Trends and management of wolf-livestock conflicts in Minnesota. Research publication 181. U.S Fish and Wildlife Service, Washington, D.C.

Garcia, J., and R. A. Koelling. 1966. Relation of cue to consequences in avoidance learning. Psychonomic Science 4:123-124.

Gustavson, C. R., J. Garcia, W. G. Hankins, and K. W. Rusiniak. 1974. Coyote predation control by aversive conditioning. Science 184:581583.

Haber, G. C. 1996. Biological, conservation, and ethical implications of exploiting and controlling wolves. Conservation Biology 10:10681081.

Harris, C. E., and F. F. Knowlton. 2001. Differential responses of coyotes to novel stimuli in familiar and unfamiliar settings. Canadian Journal of Zoology 79:2005-2013.

Klunder, C. S., and M. O'Boyle. 1979. Suppression of predatory behaviors in laboratory mice following lithium chloride injections or electric shock. Animal Learning and Behavior 7:13-16.

Koehler, A. E., R. E. Marsh, and T. P. Salmon. 1990. Frightening methods and devices/stimuli to prevent mammal damage - a review. Proceedings Vertebrate Pest Conference 14:168-173.

Krane, R. V., and A. R. Wagner. 1975. Taste aversion learning with a delayed shock US: implications for the generality of the laws of learning. Journal of Comparative and Physiological Psychology 88:882889.

Linhart, S. B., J. D. Roberts, S. A. Shumake, and R. Johnson, 1976. Avoidance of prey by captive coyotes punished with electric shock. Proceedings of the Vertebrate Pest Conference 7:302-306.

Linhart, S. B., R. T. Sterner, G. J. Dasch, and J. W. Theade. 1984. Efficacy of light and sound stimuli for reducing coyote predation upon pastured sheep. Protection Ecology 6:75-84.

Mason, J. R., J. A. Shivik, and M. W. Fall. 2001. Chemical repellents and other aversive strategies in predation management. Endangered Species Update. 18:175-181.

Musiani, M., and E. Visalberghi. 2001. Effectiveness of fladry on wolves in captivity. Wildlife Society Bulleting 29:91-98.

Musiani, M., C. Mamo, L. Boitani, C. Callaghan, C. C. Gates, L. Mattei, E. Visalberghi, S. Breck, and G. Volpi. 2003. Wolf depredation trends and the use of fladry barriers to protect livestock in western North America. Conservation Biology 17:1538-1547.

Primm, S. A., and T. W. Clark. 1996. Making sense of the policy process for carnivore conservation. Conservation Biology 10:1036-1045.

Quigley, T. M., H. R. Sanderson, A. R. Tiedemann, and M. L. Mcinnis. 1990. Livestock control with electrical and audio stimulation. Rangelands 12:152-155.

Shivik, J. A., M. M. Jaeger, and R. H. Barrett. 1996. Coyote movements in relation to spatial distribution of sheep. Journal of Wildlife Management 60:422-430.

Shivik, J. A., and D. J. Martin. 2001. Aversive and disruptive stimulus applications for managing predation. Pages 111-119 in M. C. Brittingham, J. Kays, and R. McPeake, editors. Proceedings of the ninth wildlife damage management conference. Pennsylvania State University, University Park, Pennsylvania.

Shivik, J. A., V. Asher, L. Bradley, K. Kunkel, M. Phillips, S. W. Breck, and E. Bangs. 2002. Electronic aversive conditioning for managing wolf predation. Proceedings of the Vertebrate Pest Conference 20:227231.

Smith, M. E., J. D. C. Linnell, J. Odden, and J. E. Swenson. 2000. Review of methods to reduce livestock depredation: II. aversive conditioning, deterrents, and repellents. Acta Agriculture Scandinavia 50:291-303

Soulé, M. E. 1986. Conservation biology and the real world. Pages 1-12 in M. E. Soulé, editor. Conservation biology: the science of scarcity and diversity. Sinauer, Sunderland, Massachusetts.

Sterner, R. T. 1995. Cue enhancement of lithium-chloride-induced mutton/sheep aversions in coyotes. Great Plains Wildlife Damage Control Workshop Proceedings 12:92-95.

Tiedemann, A. R., T. M. Quigley, L. D. White, W. S. Lauritzen, J. W. Thomas, and M. L. Mcinnis. 1997. Electronic (fenceless) control of livestock. Research paper PHW-XXX. U.S. Forest Service, Pacific Northwest Research Station, Portland, Oregon.

U.S. Fish and Wildlife Service (USFWS), Nez Perce Tribe, National Park Service, and U.S. Department of Agriculture Wildlife Services. 2002. Rocky Mountain wolf Recovery 2001 annual report. USFWS, Ecological Services, Helena, Montana.

Wydeven, A. P., R. N. Schultz, and R. P. Thiel. 1995. Monitoring a recovering gray wolf population in Wisconsin, 1979-1995. Pages 147-156 in L. N. Carbyn, S. H. Fritts, and D. R. Seip, editors. Ecology and conservation of wolves in a changing world. Canadian Circumpolar Institute, Edmonton, Alberta.

Wydeven, A. P., J. E. Wiedenhoeft, R. N. Schultz, R. P. Thiel, S. R. Boles, and B. E. Kohn. 2002. Progress report of wolf population monitoring in Wisconsin for the period October 2001-March 2002. Wisconsin Department of Natural Resources, Park Falls.

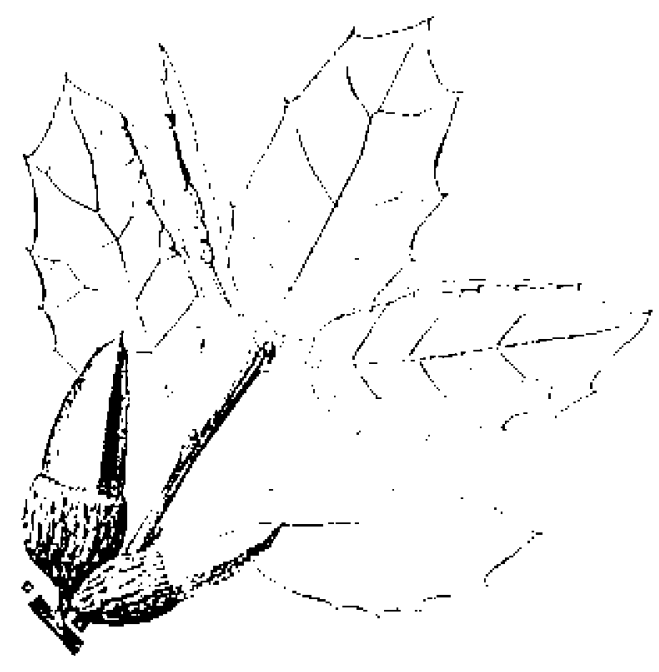

